\title{
軟部好酸肉芽腫の治療経験
}

\author{
佐藤 幸弘・山本 英一・宮本 永祥 \\ 秋定健・中川 信子・折田 洋造
}

\section{Treatment of Soft Tissue Eosinophilic Granuloma}

\author{
Yukihiro Sato, Hidekazu Yamamoto, Hisayoshi Miyamoto, \\ Takeshi Akisada, Nobuko Nakagawa and Yozo Orita \\ (Kawasaki Medical School)
}

\begin{abstract}
A 43-year-old male had eosinophilic granuloma of the soft tissue in the parotid region. The treatment of this disease has not been established. The possibilities are surgery, radiation, steroid therapy, antiallergic therapy, antiinflammatory therapy, etc. Single therapy is not very effective, so a combination of these therapies should be used. Surgery, low dose radiation, antiallergic therapy, antiinflammatory drugs and steroids were effective. During outpatient follow-up care, the drugs should be changed when the tumor increases in size.
\end{abstract}

Key words: treatment, soft tissue eosinophilic granuloma, parotid region, combination therapy

はじめに

軟部好酸肉芽腫は木村氏病ともいわれている が，慢性に経過し，無痛性の軟部組織の腫瘤， あるいはリンパ節の腫脹を主訴とし，血液の好 酸球の増多および特異な病理像 ${ }^{1)}$ を示すととを 特徴とする．現在原因についてはアレルギーの 関与が疑われているが，原因不明である，治療 についても薬物療法, 放射線療法, 手術等様々 である．今回著者らは右耳下腺部に発生し，併 用療法により緩解し, 経過観察中の軟部好酸肉 芽腫の 1 例を経験したので，文献的考察を加え て報告する。

\section{症例}

症例：43歳 男性

\section{主訴：右耳下腺部腫脹}

既往歴：特記すべきととなし

家族歷：幼小児期より右耳介後部腫瘤が持 続. 昭和 57 年 1 月ごろ右耳下腺部腫脹に気付き 他院にて同部位腫瘤摘出術施行し組織学的には 良性であった。同年 8 月，同部位腫脹し搔㾕感 出現するあ放置していたとてろ腫脹増大するた め昭和 59 年 1 月 11 日当科受診。

1。全身所見

体格中等度，栄養状態良好。頸部リンパ節触 知せず，心音は整で雑音無し，呼吸音正常.

\section{2. 局所所見}

右耳下腺部を中心に腫脹を認め（図 1 ）圧痛 はないが，軽度発赤，および癒着が認められ 
た.

\section{3. 耳下腺造影検査}

耳下腺造影にて腺葉を前方に圧排している像 が得られたが, 腫瘍膿染等の所見はなく, 良性 腫瘍を疑う所見であった（図2）。

\section{C T}

CT scan にて耳下腺部から顎下部にかけて inhomogenous で一部 cystic な tumor が 見られた。 また contrast enhancement にて enhance された（図3）.

inhomogenous で enhance されたとと,

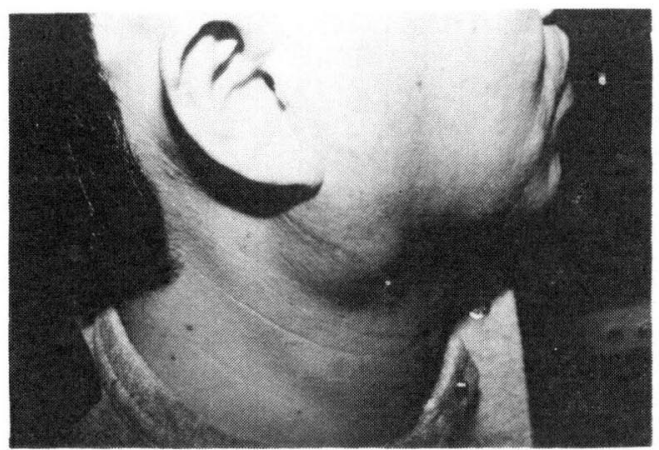

図， 右耳下腺部腫脹

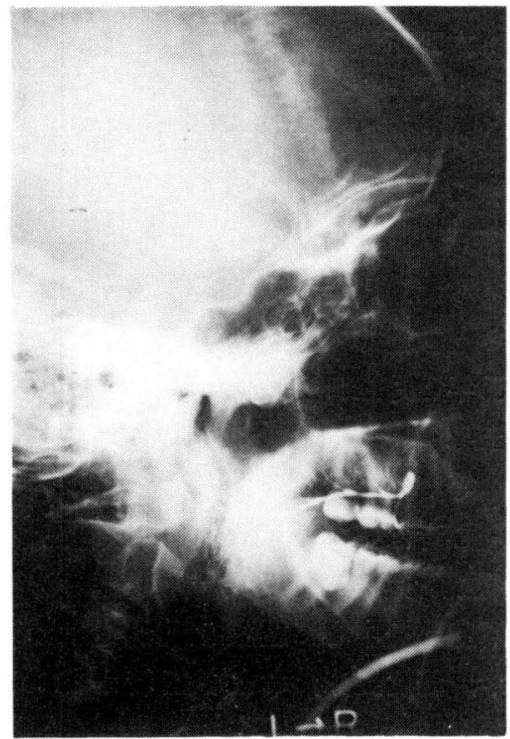

図 2 耳下腺造影にて腺葉を前方に圧排
腫瘤の可動性低下より覀性腫瘍む疑われた。

5. Echo

CT scan 上同様に inhomogenous で一部 cystic な tumorが見られた（図4）。

6. R I シンチグラフィー

${ }^{67} \mathrm{Ga}$ シンチグラフィーにて 陽性所見はみら れず， ${ }^{99 \mathrm{~m}} \mathrm{TcO}_{4}$ にてむ分祕能は左右差なく正 常であった。 ${ }^{67} \mathrm{Ga}$ シンチで陽性をしわさなか ったことより炎症および悪性腫湯は考えにくか った。

7. 末佾血液検査……括弧内の数值は正常範 囲

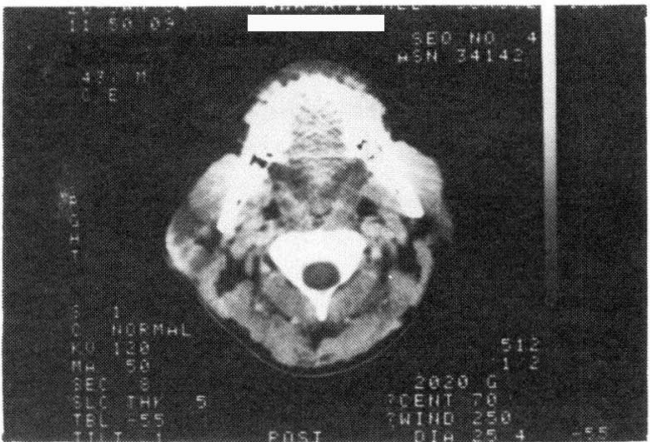

図 3 一部 cystic で, contrast enhancement にて enhance される

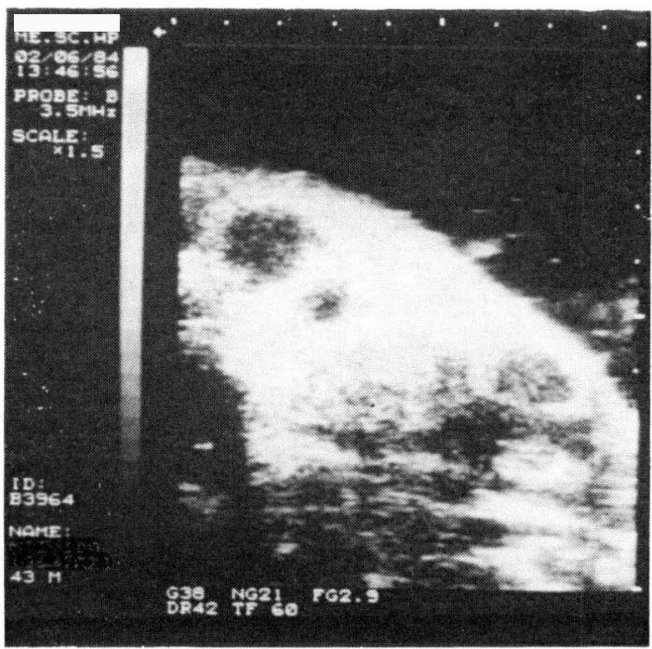

図 4 一部 cystic 
$\mathrm{Rbc} \quad 445 \times 10^{4}\left(410-550 \times 10^{4}\right)$

WBC $6000(3500-7500)$

N.Band $\quad 13 \%(2-10)$

N.seg $\quad 41 \%(50-70)$

Eosino 23\% (1-5)

Lymmpbo $29 \%(20-40)$

WBC の増加は認められず正常範囲内である が好酸球の著明な増加が認められる.

8. 免疫学的検査

血清免疫グロブリン

$\begin{array}{ll}\mathrm{IgE} & 4700 \mathrm{u} / \mathrm{ml}(20-400) \\ \mathrm{IgG} & 1180 \mathrm{mg} / \mathrm{dl}(700-1600) \\ \mathrm{Ig} \mathrm{A} & 330 \mathrm{mg} / \mathrm{dl}(90-450) \\ \mathrm{IgM} & 122 \mathrm{mg} / \mathrm{dl}(60-280)\end{array}$

$\mathrm{IgE}$ の著明な増加は認められ，7の結果を 含めて考えると何らかの機序によるアレルギー 状態があるととが考えられる.

RAST 法

アスペルギルス $( \pm)$, カンジダ( $(-)$

ぞちらも抗原とは考えにくい.

9. 他の検査

IfII液化学検查, 尿検査, E C G, 胸部 X 線上 も特記すべきことなく，粪便検査にてむ寄生虫 卵は認められなかった。

上記所見より良性腫瘍，あるいは軟部好酸肉 芽腫を考えたが，CT所見および局所所見にて 悪性の可能性むあるため手術を施行した.

耳下腺部は再手術であること屯関与して周囲 結合織との癒着屯強く, 被膜屯はっきりせず

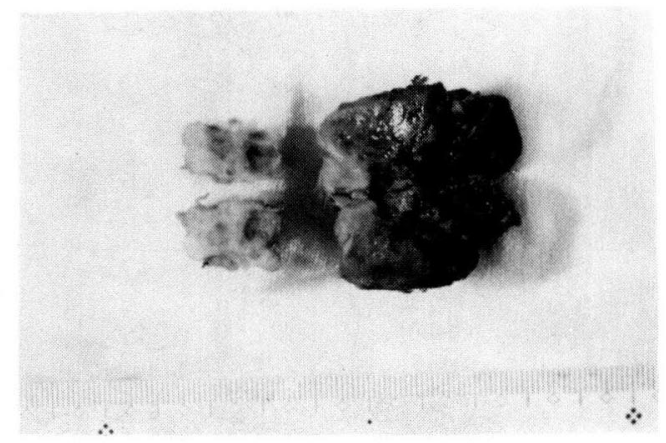

図 5 摘出された腫瘤 tumor よりの出血も多量であった. 正常の 耳下腺は存在し, tumor は耳下腺内側にもぐ りこんでいるような発育をしていた。そのため 顔面神経麻盘等の危険性を考え全摘出をあきら め手術を終了した。

10. 摘出した腫瘤を示す（図 5 ）.

割面は cystic で弾性であった。

11. 組織学的検査 (図6).

組織標本ではリンパ濾胞の増生之好酸球, リ ンパ球の著明な浸潤があり軟部好酸肉芽腫之診 断した.

11. アレルゲン検索

表 1 のようにアレルゲンを検索し，八ウスダ

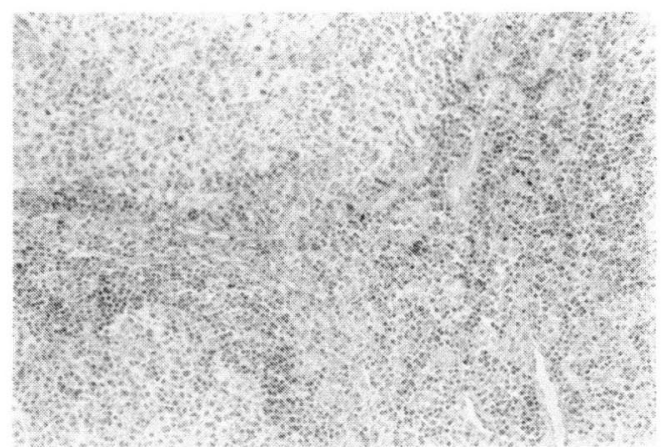

図 6 リンパ滤胞の増生, 好酸球, リンパ球の 著明な浸潤. H一E染色

表|アレルゲン検索

\begin{tabular}{lcc}
\hline \hline & \multicolumn{1}{c}{15 分 } & 30 分 \\
\hline カンジダ & $5 \times 5 / 5 \times 5$ & $(-)$ \\
アスペルギールス & $(-)$ & $(-)$ \\
ヘウスダスト & $5 \times 5 / 11 \times 6$ & $(-)$ \\
ススキ花粉 & $7 \times 10 / 14 \times 35$ & $10 \times 10 / 11 \times 11$ \\
スギ花粉 & $(-)$ & $(-)$ \\
アカマツ花粉 & $(-)$ & $(-)$ \\
絹 & $(-)$ & $(-)$ \\
畳 & $(-)$ & $(-)$ \\
綿 & $(-)$ & $(-)$ \\
クラドスポルム & $(-)$ & $(-)$ \\
ペニシリウム & $(-)$ & $(-)$ \\
アルテルナリヤ & $(-)$ & $(-)$ \\
羽毛 & $(-)$ & $(-)$
\end{tabular}


スト，ススキ花粉に軽度の反応を認めたが，抗 原と思われるものは存在しなかった。

手術により腫脤は減少し, 検査にて好酸球数 は術前 $30 \%$ より手術翌日10\%と顕著な低下を示 した。しかし腫脹が持続するため消炎鎮痛剂,

Fenbufen（商品名，ナパノール）を併用しつ つ, $6 \mathrm{meV}$ Electron で Total 20Gy の照射 を行なった．さらに腫脹が認められたため, Predonisolone $30 \mathrm{mg} /$ day より経口投与し漸減 した。この時点で腫脹はほぼ消失し入院後約 1 ケ月で退院した。現在外来にて約 1 年の経過観 察を行なったが，1984年 4 月ごろより腫脤出現 し同時に好酸球数屯増加したため抗アレルギー 作用のある Glycyrrhizin を投与し肉眼的にも 腫脹減退し好酸球数も減少した。しかし同年 8 月ごろ再度腫脹出現し, 効果の持続が長く, 強い 抗炎症作用の期待できる Piroxicam（商品名, フェルデン）に抗炎症剂を変更したところ腫脹 屯軽減し好酸球数屯低值におちついている（表 2 ).

\section{考察}

本疾患は石井 ${ }^{1)}$ によれば16〜15歳にピーク があり青少年から壮年期に好発し，平均年歯 は24.8歳である．男女比は 6.3 対 1 で男性に多 い. 受診するまでの平均期間は 6.9 年と長期で ある，好発部位は，耳下腺およびその周囲リン パ節で石井 ${ }^{1)}$ は73.9\%が頭頸部領域に発生して いると述べている．伊藤ら ${ }^{2)}$ の統計でも耳下腺 部が最も多い.

検査所見では白血球増加，好酸球増多を示す ことが多いままた腫瘤の消長と好酸球数および $\mathrm{IgE}$ 值が相関する.

病理組織像では, リンパ濾胞の増生が著し く, 各濾胞間に多数の好酸球の侵潤を認めるこ とを特徴とする ${ }^{3)}$. また木村氏病をリンパ節に 限局するむのは例外とする意見があるが，石井 の報告にあるように病理学的には差はない(1)13). 成因については不明であるが，アレルギー， 内分泌障害 ${ }^{14)}$, 自己免疫等があげられている. しかしアレルギー説があっとも有力で検査所見 上，好酸球数抢よび $\mathrm{IgE}$ 值が高值を示すとと

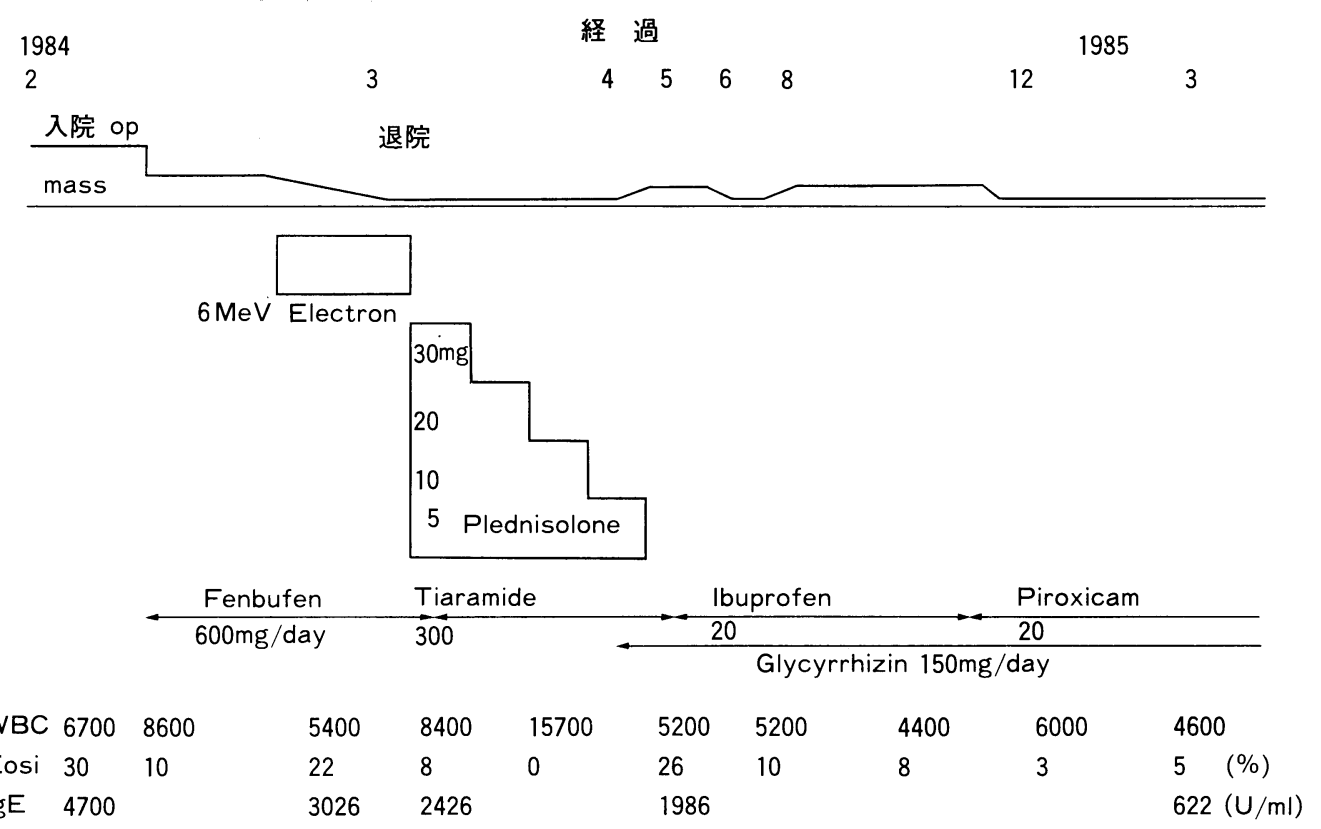




\section{とあ合致する.}

予後については竹山ら ${ }^{11}$ は重篤な経過すなく おおむね良好であるが，再発を繰り返す例もあ ると報告している.

治療方法については現在確立されたものはな く試行錯誤の段階である。しかし今日行なわれ ているものとして, 手術療法, 放射線療法, steroid 療法, 抗アレルギー療法等, およびて れらの併用療法がある. 石井1 ${ }^{1)}$ 亿れば手術に よる摘出，ステロイド，放射線等による単独療 法によるものでは再発率が高く，二者併用ある いは，三者併用では再発した症例は少ないと報 告している，併用療法を行なうにあたり，各療 法について考察してみたい.

\section{1 ) 手術療法}

古田ら4)によれば腫瘤を含めて周囲リンパ節 群を enbloc に摘出できるが他の重要な組織, 臟器を損傷する危険性が大きいことをあげてい る。本症例のように耳下腺部に発生した例にお いては顔面神経の損傷を考慮しなければならず 手術適応については慎重にならなければならな い.

\section{2 ）放射線療法}

綿貫ら ${ }^{5}$ は first choice にすべき治療と述 べている，しかし一番問題にすべきてとは，照 射による腫瘍の悪性化および照射による，後遺 症である，そのため照射線量については考慮し なければならないが，黒川ら によれば40４5 Gy が必要で効果が現われるのは 10Gy 以降 であり，20〜30Gy までほとんど縮小せず，急 速に消失していくこともあると述べている.

\section{3 ) Steroid 療法}

Steroid は投与中は効果があるが，投与中止 すると好酸球増多, 腫瘤の再発がみられる傾向 がある17)18).

4 ）抗アレルギー療法

単独施行のみで有効であるととは少ない"1). しかしカンジダ皮内反応陽性例に減感作療法が 有効であった報告あある ${ }^{10)}$. 本症例では抗原は 認められなかったため減感作療法は施行せず,
Glycyrrhizin 内服を行なった。

\section{5 ) 消炎剂}

重篤な副作用がおこることが少ないので併用 すべきものであろう.

他に免疫抑制剂である，6MP，マイトマイ シン,ナイトロジェンマスタード，エンドキサ ン15)16)19)等の報告もあるが効果は顕著でないと 言われている，以上の治療方法をみると，それ ぞれ利点, 欠点はあるが軟部好酸肉芽腫の治療 において一番重要なととは併用療法をおこな い, 症状の緩解にあわせて各々の治療方法を検 討していくことだと思われる，本症例では手術 後放射線にて remission に持ち込みたいと考 えたが，効果が期待したほどでなかったため， steroid および抗アレルギー療法を追加した。 また外来経過観察においても消炎剂の変更等も 行ない現在の状態を保っている.

\section{まとめ}

43歳男性に発症した軟部好酸肉芽腫の一例に ついて報告した。治療方法は現在試行錯誤の段 階であるが，手術療法，放射線療法，ステロイ ド, 抗アレルギー療法, 抗炎症剤等の治療法が ある，単独療法はあまり有効でないので併用療 法を行なうべきである. 本症例においては手術 療法, 比較的小線量の放射線療法, 抗アレルギ 一療法, 抗炎症剤, ステロイド等の治療により 緩解し経過観察中である．また外来にての経過 観察においては腫瘤の増大があれば適宜薬剂を 変更するのも有効である.

なお, 本論文の要旨は日本耳鼻咽喉科学会第10回中 国地方部会連合会（1984年6月17日）において発表し た.

\section{文献}

1) 石井正則：木村氏病について. 耳展 $25: 407$ 416, 1982.

2) 伊藤善一, 他：軟部組織好酸肉芽腫について一 自験 5 例 と文献的考察一. 臨床外科 $21: 1135$ $\sim 1141,1966$. 
3）石川栄世，他：好酸性リンパ河胞様構造增生性肉 芽腫（木村氏病）の病理的研究. 日本網内系学 会誌 $20: 138 \sim 148,1980$.

4 ）古田 茂, 他：顎下部に発生した軟部好酸肉芽腫 の 1 例. 耳㬋 51:301 305, 1979.

5 ）綿貫 菭, 他：軟部組織の好酸球性肉芽腫につい て-12例の経験と文献的考察一. 臨床外科 17 : $5 \sim 17,1962$.

6）黒川久枝，他：軟部好酸肉芽腫（いわゆる木村氏 病）の放射線治燎. 癌の臨床 $18: 712 \sim 716$, 1972.

7 ）本田哲朗, 他：軟部好酸肉芽腫の治療経験. 耳鼻 臨床 $77: 47 \sim 51,1984$.

8 ）小林仁和, 他：軟部好酸球肉芽腫の一症例. 耳鼻 $28: 1108 \sim 1113,1982$.

9 ）神崎 仁，他：軟部好酸肉牙腫（木村氏病）の二 症例. 耳喉 $43: 391 \sim 397,1971$.

10）佐々木好久, 他：軟部好酸肉芽腫とアレルギー。 耳喉 $\quad 43: 195 \sim 200,1971$.

11）竹山勇, 他：軟部好酸球肉芽腫の 1 例. 耳喉 $43: 699 \sim 708,1971$.
12）山口宗彦，他：軟部好酸肉牙腫症の臨床，耳喉 $45: 639 \sim 645,1973$.

13）所 安夫：リンパ節の腫煌（第14回). 臨床外科 $17: 175 \sim 181,1962$.

14）木村信良，他：Mikulicz症候群と Parotin の関 係について. 日外会誌 $60: 369 \sim 370,1959$.

15）田中 聰：他：孤立性皮下腫瘤を主徴としたエオ ジン好性細胞肉芽腫の 2 例. 癌の臨床 $6: 93 \sim$ 96, 1960.

16）藤野和夫，他：皮下好酸球肉芽腫の 2 例. 外科 $25: 871 \sim 873,1963$.

17）安西 喬, 他：リンパ沪胞様構造および好酸球增 多を示す 1 種の肉芽腫（木村氏病）。日皮会誌 $73: 552,1963$

18）織方明詔, 他：Eosinophilic Lymphoid Granuloma. 西日皮膚 $40: 57 \sim 63 ， 1978$.

$$
\left(\begin{array}{l}
\text { 原稿到着：昭和 } 60 \text { 年 } 9 \text { 月 } 5 \text { 日 } \\
\text { 別刷請求先：佐藤幸弘 } \\
\text { 厂701-01 倉敷市松島 } 577 \\
\text { 川崎医科大学耳鼻咽喉科学教室 }
\end{array}\right)
$$

